\title{
PENGUKURAN WAKTU BAKU DAN ANALISIS BEBAN KERJA PADA PROSES FILLING DAN PACKING PRODUK LULUR MANDI DI PT. GLORIA ORIGITA COSMETICS
}

\author{
Measurement of Standard Time and Analysis of Workloads in The Filling Process \\ and Packing of Shower Scrub Products at PT. Gloria Origita Cosmetics
}

Endah Meila Sari ${ }^{1}$ dan M. Muchtar Darmawan ${ }^{1 *}$

${ }^{1}$ Jurusan Teknik Industri, Fakultas Teknik, Universitas Pancasila, Jakarta, Indonesia

Informasi artikel

Diterima: 20/01/2020

Direvisi : 21/01/2020 Disetujui: 22/01/2020

\begin{abstract}
Abstrak
PT. Gloria Origita Cosmetics adalah perusahaan yang bergerak dalam industri kecantikan dan perawatan tubuh (skin care). Salah satu produk yang diproduksi PT Gloria Origita Cosmetics adalah Lulur Mandi Purbasari kemasan 235 gr. Dalam proses produksinya tidak ada standar waktu yang diterapkan dalam proses produksinya sehingga pihak perusahaan belum dapat menentukan secara pasti berapa kebutuhan jumlah tenaga kerja seharusnya sesuai dengan beban kerja dari masing-masing stasiun kerja. Penelitian ini dilakukan untuk menetapkan waktu baku dan beban kerja pada produksi Lulur Mandi Purbasari kemasan 235 gr tersebut. Proses pengamatan dilakukan dibagian filling dan packing lulur mandi Purbasari dan pengambilan data waktu kerja dilakukan dengan menggunakan jam henti (Stopwatch) serta metode penyesuaian yang digunakan adalah westinghouse. Metode penelitian yang dilakukan adalah dengan menganalisis pekerjaan yang dilakukan oleh operator yang ada di ruang filling dan packing, menghitung waktu kerja operator, memperkirakan jumlah permintaan yang akan diterima, menentukan beban kerja dari masing-masing stasiun kerja, dan menentukan jumlah tenaga kerja yang sesuai dengan beban kerja. Hasil perhitungan diperoleh bahwa berdasarkan perhitungan waktu baku maka diperoleh beban kerja yang kurang dari $100 \%$ adalah pada proses menutup pot, memasang shrink label, dan memasang capseal, sehingga pada proses tersebut dilakukan pengurang masing-masing satu operator, sedangkan pada proses inspeksi hasil perekatan label (shrinking process) terdapat beban kerja yang berlebih yaitu $114 \%$ maka diperlukan penambahan overtime pada proses inspeksi ini.
\end{abstract}

Kata Kunci: Beban kerja, lulur mandi, pengukuran waktu dengan jam henti, tenaga kerja, waktu baku, westinghaouse.

\begin{abstract}
PT. Gloria Origita Cosmetic is a company that manufactures a beauty and body care product. One of the products that produced by PT Gloria Origita Cosmetics Is Lulur Mandi Purbasari $235 \mathrm{gr}$. In the production process there is no standard time applied in the production process so that the company can't decide exactly how many man power should be needed according to the work load of each work station. The observation is to determine about the standard time and workload in the prodaction of $235 \mathrm{gr}$ packaged Lulur Mandi. The observation collecting the working time data in filling and packing section of Lulur Mandi Purbasari is using a stopwatch and performance rating used is westinghouse system's rating. The observation method is by analyzing the man power work in filling and packing section, calculate the man power working time, estimate the amount of demand that company will receive, decide the work load of each work station and decide the amount of man power according to the work load of each work station. The calculation results based on the calculation of the standard time, state that the workload is less than $100 \%$ in the process of closing the pot, put on the shrink label and put on the capseal. So in that process the company must decrease one man power of each process, while in inspection process the result of shrink process there is an excessive workload about $114 \%$ so that process is need an overtime in the inspection process.
\end{abstract}

Keywords: Workload, shower scrub, stopwatch time study, man power, standard time, westinghouse.

*Penulis Korespondensi. Handphone: 085692606454

email : muchtar_darmawan@univpancasila.ac.id 


\section{PENDAHULUAN}

Kebutuhan akan produk-produk kecantikan atau skin care dewasa ini semakin meningkat, hal ini disebabkan karena seiring dengan perkembangan zaman dan taraf hidup masyarakat dimana kemajuan teknologi dan informasi yang semakin berkembang sehingga mempengaruhi kebutuhan dan gaya hidup. Tingginya tingkat permintaan konsumen tentu mempengaruhi produksi produk-produk skin care, yang mana menuntut perusahaan untuk bersaing di dunia usahanya agar dapat memperoleh keuntungan yang maksimal dan meningkatkan produktivitas produksi sehingga seluruh permintaan pasar dapat terpenuhi sehingga dapat meningkatkan tingkat kepercayaan konsumen. Tuntutan untuk meningkatkan daya saing diantara sesama produsen skin care dan dalam rangka pemenuhan permintaan yang ada, mendorong produsen untuk berproduksi secara efisien dan efektif.

Salah satu aspek yang berperan agar dapat berproduksi secara efisien dan efektif adalah dengan melakukan perencanaan sarana produksi secara baik, misalnya dalam hal ini adalah perencanaan kebutuhan jumlah tenaga kerja untuk masa yang akan datang.

Menurut Hasibuan (Hasibuan, 2005), manajemen sumber daya manusia adalah ilmu dan seni untuk mengatur hubungan dan peran tenaga kerja agar efektif dan efisien untuk membantu terwujudnya tujuan perusahaan. Oleh karena itu karyawan produksi adalah merupakan komponen penting dalam setiap kegiatan organisasi, karena manusia adalah sebagai perencana, pelaku dan penentu terwujudnya tujuan organisasi. Tujuan perusahaan tidak akan mungkin terwujud tanpa peran aktif karyawan atau tenaga kerja, meskipun alatalat yang dimiliki perusahaan sangat canggih.

Berkenaan dengan peran tenaga kerja ini, Sarah (Sarah, 2017) telah menunjukkan dalam penelitiannya di PT Covac Indonesia bahwa untuk meningkatkan produktivitas perlu dilakukan analisis yang tepat tentang beban kerja para pekerja yang melakukan aktivitas proses produksi tersebut. Penelitan dilakukan pada proses produksi pembuatan Gear Cover Packing M-013

PT Gloria Origita Cosmetics adalah salah satu perusahaan kosmetik yang berada di Indonesia yang memproduksi berbagai macam produk skin care dan make up. Produk yang memiliki permintaan pasar paling tinggi adalah produk lulur mandi, sehingga tingkat intensitas produksinya lebih tinggi diantara produk yang lain. Lulur mandi purbasari memiliki berbagai 8 varian diantaranya Lulur Mandi Bengkuang, Greentea, Mutiara, Putih, Rempah, Susu+Bengkuang, Whitening+Vit E, dan Zaitun.

PT Gloria Origita Cosmetics saat ini belum memiliki waktu baku yang dapat diterapkan dalam proses produksinya sehingga perusahaan belum dapat menentukan secara pasti berapa kebutuhan jumlah tenaga kerja seharusnya. Untuk itu perlu dilakukan pengukuran waktu baku proses produksi lulur mandi purbasari yang kemudian dapat digunakan untuk menentukan jumlah tenaga kerja yang diperlukan berdasarkan besarnya beban kerja tersebut. Selain itu dengan adanya waktu baku yang ditetapkan pada setiap stasiun kerja, hal ini akan membantu operator dalam menyelesaikan pekerjaan yang diberikan, dimana waktu baku digunakan untuk acuan maksimum dalam menyelesaikan satu unit produk sehingga pekerja tidak dapat bekerja dengan santai atau melebihi waktu baku yang telah ditentukan.

Berangkat dari uraian diatas maka penelitian ini bertujuan untuk:

a. Melakukan pengukuran waktu baku proses produksi lulur mandi purbasari

b. Menghitung beban kerja dan jumlah operator yang diperlukan pada proses pembuatan produk lulur mandi purbasari di PT Gloria Origita Cosmetics.

Area penelitian dilakukan pada proses filling dan packing yang merupakan final process dari pembuatan lulur mandi tersebut.

\section{TEORI DASAR}

\section{Pengukuran Waktu}

Penelitian kerja dan analisa metoda kerja pada dasarnya akan memusatkan perhatiannya pada bagaimana suatu macam pekerjaan akan diselesaikan. Pengukuran waktu kerja ini berhubungan dengan usahausaha untuk menetapkan waktu baku yang dibutuhkan untuk menyelesaikan suatu pekerjaan. Waktu baku ini merupakan waktu yang dibutuhkan oleh seorang pekerja yang memiliki tingkat kemampuan rata-rata untuk menyelesaikan pekerjaan. Dalam hal ini meliputi waktu kelonggaran yang diberikan dengan memperhatikan situasi dan kondisi pekerjaan yang harus diselesaikan. 


\section{a. Pengukuran Waktu Kerja Dengan Jam Henti (Stopwatch Time Study)}

Pengukuran waktu dengan jam henti (Stopwatch Time Study) diaplikasikan baik pada pekerjaan-pekerjaan yang dilakukan secara singkat maupun pada pekerjaan sifatnya berulang-ulang (repetitive). Langkah-langkah yang diperlukan sebelum dan saat melakukan pengukuran adalah sebagai berikut (Sutalaksana, 2006):

1. Penetapan Tujuan Pengukuran

2. Melakukan penelitian Pendahuluan

3. Memilih dan melatih Operator

4. Mengurai pekerjaan atas elemenelemen

5. Menyiapkan perlengkapan pengukuran.

6. Melakukan pengukuran

\section{b. Kecukupan Data}

Uji kecukupan data diperlukan untuk memastikan bahwa data yang telah dikumpulkan dan disajikan dalam laporan pengukuran tersebut adalah cukup secara obyektif. Berikut adalah rumus yang digunakan untuk menguji tingkat kecukupan data (Sutalaksana, 2006):

$$
N^{\prime}=\left[\frac{K / S \sqrt{N \Sigma x i^{2}-(\Sigma x i)^{2}}}{\Sigma x i}\right]^{2}
$$

Dimana :

$$
\begin{aligned}
& \mathrm{k}=\text { konstanta yang nilainya bergantung } \\
& \text { pada tingkat keyakinan yang diambil } \\
& \mathrm{S}=\text { Derajat Ketelitian } \\
& \mathrm{N}=\text { Jumlah Data Pengamatan } \\
& \mathrm{N} \text { ' = Jumlah Data Teoritis } \\
& \mathrm{X}=\text { Data Pengamatan }
\end{aligned}
$$

Jika $N^{\prime} \leq \mathrm{N}$ maka data dianggap cukup, namun jika $N^{\prime}>\mathrm{N}$ data tidak cukup (kurang) dan perlu dilakukan penambahan data.

\section{c. Keseragaman Data}

Untuk memastikan bahwa data yang terkumpul berasal dari sistem yang sama, maka dilakukan pengujian terhadap keseragaman data. Adapun rumus yang digunakan dalam pengujian keseragaman data adalah (Sutalaksana, 2006):

1) Menghitung harga rata-rata dalam subgrup dengan menggunakan rumus :

$\bar{X}=\frac{\Sigma x_{i}}{n}$

Dengan $\mathrm{n}=$ ukuran subgrup

2) Menghitung rata-rata dari rata-rata subgrup.
$\overline{\bar{X}}=\frac{\Sigma \bar{x}}{g}$

Dimana :

$\bar{X}=$ Nilai rata-rata subgrup.

$\mathrm{g}=$ Banyaknya sub grup.

3) Menghitung standar deviasi dari rata-rata subgrup dengan :

$\sigma_{\bar{x}}=\frac{\sigma}{\sqrt{n}}$

Dimana :

$\sigma_{\bar{x}}=$ Standar deviasi dari rata-rata subgrup.

$\mathrm{n}=$ Ukuran subgrup.

$\sigma=$ Standar deviasi populasi

4) Menentukan batas kontrol atas (BKA) dan batas kontrol bawah (BKB) :

$$
\begin{aligned}
& \text { BKA }=\overline{\bar{x}}+3 \sigma_{\bar{x}} \\
& \text { BKB }=\overline{\bar{x}}-3 \sigma_{\bar{x}}
\end{aligned}
$$

Hasil pengukuran dikatakan seragam bila semua harga rata-rata sub group berada dalam batas kontrol.

\section{d. Perhitungan Waktu Baku}

Apabila semua pengukuranpengukuran telah selesai, yaitu semua data yang didapat memiliki keseragaman yang dikehendaki, dan jumlahnya telah memenuhi tingkat-tingkat ketelitian dan keyakinan yang diinginkan, maka selesailah pengukuran waktu.

\section{1) Waktu Siklus}

Waktu siklus atau cycle time adalah waktu yang diperlukan untuk membuat satu unit produk pada satu stasiun kerja (Purnomo, 2003).

Waktu siklus dihitung dengan menggunakan rumus:

$$
W_{s}=\frac{\sum x i}{N}
$$

Dimana :

$\mathrm{W}_{\mathrm{s}}=$ Waktu siklus

$\mathrm{Xi}=$ Waktu pengukuran/ pengumpulan data $\mathrm{N}$ = Jumlah pengamatan

\section{2) Waktu Normal}

Waktu normal merupakan waktu kerja yang telah mempertimbangkan faktor penyesuaian. Rumus waktu normal adalah sebagai berikut:

Waktu normal $=$ waktu siklus $\times \mathrm{P}$ 
Dimana:

$$
\begin{aligned}
& \mathrm{P}= \text { Tingkat Penyesuaian Kerja (Rating } \\
& \text { Performance) }
\end{aligned}
$$

\section{3) Waktu Baku/standar}

Waktu standar adalah waktu yang sebenarnya digunakan operator untuk memproduksi satu unit dari data jenis produk. Waktu baku dihitung dengan menggunakan rumus sebagai berikut.

Waktu baku $=$ Waktu Normal $X \frac{100 \%}{100 \% \text { - Allowance }}$

\section{e. Penyesuaian Dan Kelonggaran}

Sistem kerja tidak dapat terlepas dari dua aspek, yaitu pemberian penyesuaian dan pemberian kelonggaran.

1) Tingkat Penyesuaian Kerja (Rating Performance)

Pengukuran harus mengamati kewajaran kerja yang ditunjukkan operator. Metode-metode penyesuaian (Sutalaksana, 2006):

a) Westinghouse System's Rating

Pengukuran Kelonggaran dengan metode westinghouse mengarahkan pada penilaian pada empat faktor yang dianggap menentukan kewajaran atau ketidak wajaran dalam bekerja. yaitu : keterampilan, Usaha, Kondisi Kerja, dan Konsistensi serta setiap faktor dibagi dalam kelasnya dengan nilai masing masing. Untuk ini westinghouse telah berhasil membuat suatu tabel performance rating yang berisikan nilai-nilai angka yang berdasarkan tingkatan yang ada untuk masingmasing faktor tersebut.

b) Skill dan Effort Rating

Waktu baku dinyatakan dengan angka "Bs" dengan mempertimbangkan allowance waktu lainnya Di sini Bedaux menetapkan angka 60 Bs sebagai performace standard yang harus dicapai oleh seorang operator.

c) Synthetic Rating Metode untuk mengevaluasi tempo kerja operator berdasarkan nilai waktu yang telah ditetapkan terlebih dahulu, dengan kata lain membandingkan hasil pengukuran dengan waktu penyelesaian kerja sebelumnya yang telah diketahui waktunya.

d) Metode Shumard
Dilakukan dengan menyusun tabeltabel faktor penyesuaian dengan cara membagi beberapa kelas faktor penyesuaian.

\section{2) Kelonggaran}

Salah satu hal yang paling penting diperhatikan dalam pengukuran waktu adalah faktor kelonggaran. Faktor kelonggaran ini ditambahkan pada waktu normal yang telah didapatkan. Kelonggaran diberikan untuk tiga hal yaitu : untuk kebutuhan pribadi, menghilangkan rasa fatigue, dan hambatan hambatan yang tidak dapat dihindarkan.

\section{Analisis Beban Kerja}

Beban kerja atau workload adalah jumlah kegiatan yang harus diselesaikan oleh seorang ataupun sekelompok orang selama periode waktu tertentu (Dedi, 1994). Pengukuran beban kerja diartikan sebagai suatu teknik untuk mendapatkan informasi tentang efisiensi dan efektivitas kerja suatu unit organisasi. Sedangkan analisis beban kerja adalah proses untuk menetapkan jumlah jam kerja orang yang digunakan atau dibutuhkan untuk menyelesaikan suatu pekerjaan dalam kurun waktu tertentu.

\section{a. Faktor Yang Mempengaruhi Beban Kerja}

Terdapat dua faktor yang dapat mempengaruhi beben kerja seorang tenaga kerja atau operator, diantaranya adalah beban kerja eksternal dan beban kerja internal.

1) Beban kerja karena faktor eksternal adalah beban kerja yang berasal dari luar tubuh pekerja. Yang termasuk beban kerja ekternal adalah tugas itu sendiri, organisasi dan lingkungan kerja. Ketiga aspek ini sering disebut stresor.

2) Beban kerja oleh karena faktor internal adalah faktor yang berasal dari dalam tubuh itu sendiri sebagai akibat adanya reaksi dari beban kerja eksternal. Reaksi tubuh tersebut dikenal sebagai strain. Berat ringannya strain dapat dinilai baik secara objektif maupun subjektif.

\section{b. Perhitungan Beban Kerja}

Berikut ini adalah rumus perhitungan yang digunakan untuk mengukur Beban Kerja (BK): 


$$
\mathrm{BK}=\frac{\text { Waktu yang dibutuhkan }}{\text { Kapasitas waktu tersedia }}
$$

Sedangkan output yang dihasilkan dihitung dengan rumus sebagai berikut:

$$
\text { Output }=\frac{\text { Kapasitas waktu tersedia }}{\text { waktu baku }}
$$

\section{c. Perhitungan Jumlah Pekerja}

Jumlah Pekerja (JP) yang dibutuhkan dihitung berdasarkan persamaan berikut:

$$
\mathrm{JP}=\frac{\text { Waktu baku } \times \text { Demand }}{\text { Waktu tersedia }}
$$

\section{METODE PENELITIAN}

Studi pendahuluan dilaksanakan dengan melakukan observasi dan wawancara dengan pihak yang terkait, sehingga didapatkan permasalahan yang dihadapi oleh perusahaan yaitu belum adanya penetapan waktu standar yang mengakibatkan permasalahan dalam penentuan beban kerja. Pengamatan dilakukan di PT Gloria Origita Cosmetics bagian filling dan packing lulur mandi purbasari kemasan 235 gr.

Pengumpulan data primer dilakukan dengan pengukuran waktu kerja yang dibutuhkan oleh seorang operator untuk dapat menyelesaikan pekerjaannya, pengamatan waktu diukur dengan stopwatch. Data sekunder diperoleh dari perusahaan seperti profil perusahaan, data permintaan produk Lulur Mandi kemasan 235 gr yang diterima pada periode Januari 2017-Juli 2018, data jumlah operator yang ada di bagian filling dan packing, serta proses alur produksi Lulur Mandi Purbasari kemasan 235 gr.

Pengolahan data dimulai dari menentukan waktu siklus, waktu normal, dan waktu baku pada bagian filling dan packing Lulur Mandi Purbasari kemasan 235 gr, selanjutnya memperkirakan jumlah permintaan yang akan diterima per bulan Agustus 2018 - Desember 2019, selanjutnya menentukan beban output maksimal perhari, dan yang terakhir adalah menentukan jumlah operator yang sesuai untuk setiap stasiun kerja.

\section{HASIL DAN PEMBAHASAN}

\section{Penentuan Waktu Baku}

\section{a. Uji Kecukupan Data}

Didalam aktivitas pengukuran kerja ini akan digunakan 95\% tingkat kepercayaan dan
0,05 derajat ketelitian. Untuk ini maka diperoleh harga konstanta $\mathrm{k}=2$.

Tabel 1 menyajikan data waktu yang diperlukan untuk meletakkan pot kedalam mesin KM-SPA

Tabel 1 Waktu meletakkan pot ke dalam mesin KM SPA (detik)

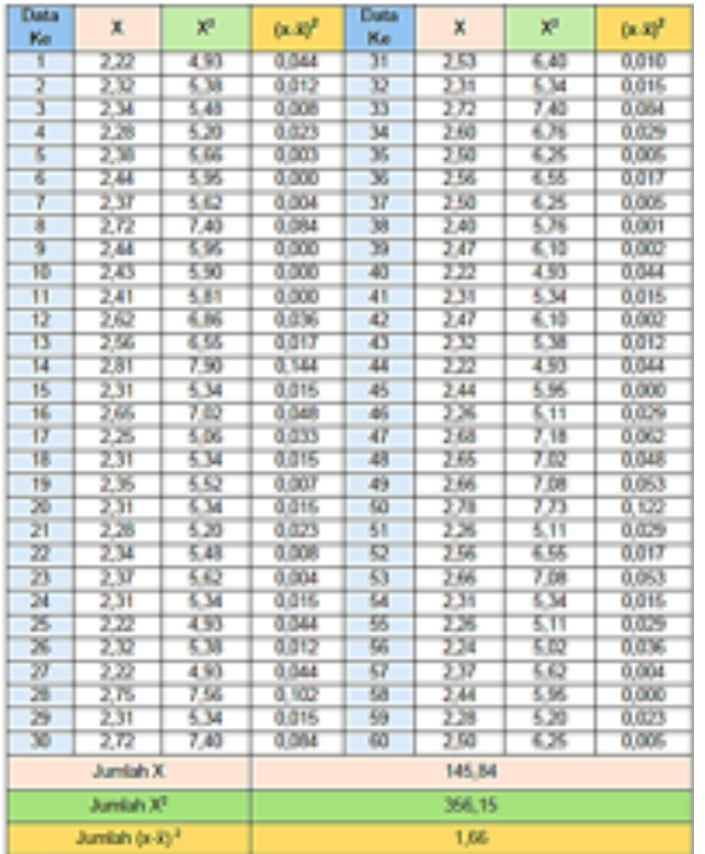

$$
\begin{aligned}
N^{\prime} & =\left[\frac{k / s \sqrt{N \Sigma x^{2}-(\Sigma x)^{2}}}{\Sigma x}\right]^{2} \\
& =\left[\frac{2 / 0,05 \sqrt{(60)(356,15)-(145,84)^{2}}}{145,84}\right]^{2} \\
& =7,50
\end{aligned}
$$

Jika $N^{\prime} \leq N$ maka data dianggap cukup. Data

\begin{tabular}{|c|c|c|c|c|c|c|}
\hline so & Fuses & $\bar{x}$ & $x^{5}$ & $\mathbf{N}$ & $\mathrm{k}$ & Rentianger \\
\hline$t$ & 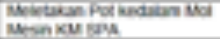 & $102, \mathrm{M}$ & sec is & $\infty$ & 750 & ithe \\
\hline 2 & Menchplat & 100,54 & 10250 & 60 & 16,30 & entip \\
\hline 3 & Menoweng swrak tated & satei & $4 r . \pi$ & $\omega 0$ & 135 & enes \\
\hline 4 & Memusung Caysed & 58,0 & 51,30 & 60 & 400 & ohip \\
\hline 5 & 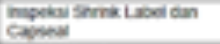 & 70,80 & 20,8 & 60 & 10,47 & atio \\
\hline 6 & 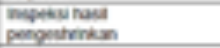 & T56, 100 & $\sec , 14$ & $\infty$ & 15,96 & pis \\
\hline 7 & 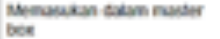 & 1900,12 & ceen,rs & $\infty$ & 5,2 & pis \\
\hline
\end{tabular}
pada Tabel 2 adalah hasil pengujian kecukupan data dari data lainnya yang telah dikumpulkan.

Tabel 2 Uji kecukupan data 


\section{b. Uji Keseragaman Data}

Pengujian dilakukan dengan menghitung batas kontrol atas dan batas kontrol bawah.

Tabel 3 Uji keseragaman data proses filling meletakan pot kedalam mesin KM SPA

\begin{tabular}{|c|c|c|c|c|c|c|c|c|c|c|}
\hline \multicolumn{11}{|c|}{ Stassiun Kerja Fitting } \\
\hline Pengukuran & & & & & Sub & Grup & & & & \\
\hline ke & 1 & 2 & 3 & 4 & 5 & 6 & 7 & 8 & 9 & 10 \\
\hline 1 & 2,22 & 2,32 & 2,34 & 2,28 & 8, 38 & 2,44 & 42,37 & $2, n$ & 2,44 & 2,43 \\
\hline 2 & 2,45 & 2,62 & 2,56 : & 2,21 & 2,31 & 2,65 & 2.25 & 2,31 & 2,35 & 2,3 \\
\hline 3 & 2,28 & 2,34 & 2,37 & 2,31 & 2,22 & 2,32 & 2,22 & 2,75 & 2,31 & 2,72 \\
\hline 4 & 2,53 & 2,31 & $2, n$ & 2,60 & 2,50 & 2,5s & 2,50 & 2,40 & 2,4 & 2,22 \\
\hline 5 & 2,31 & 2,47 & $2, \mathbf{n}$ & 2,22 & 2,44 & 2,26 & 2,68 & 2,65 & 2,66 & $2, \pi s$ \\
\hline 6 & 2.25 & 2,56 & 2,66 & 2,31 & 2,26 & 224 & 2,37 & 2,4 & 2.28 & 2.50 \\
\hline Rata-Rata & 2,34 & 2,44 & 2,50 & 2,42 & 2,35 & 2,41 & 2,46 & 2,55 & 2,4 & $2,4)$ \\
\hline
\end{tabular}

Setelah dicari rata-rata dari masingmasing sub grup maka selanjutnya dihitung rata-rata dari sub grup tersebut sebagai berikut :

$$
\begin{aligned}
\overline{\bar{X}} & =\frac{\Sigma \bar{x}}{n} \\
& =\frac{24,31}{10} \\
& =2,43
\end{aligned}
$$

Menghitung standar deviasi sebenarnya dari waktu penyelesaian dengan cara sebagai berikut :

$$
\begin{aligned}
\sigma & =\sqrt{\frac{\sum(x-\bar{x})^{2}}{N}} \\
& =\sqrt{\frac{1,66}{60}} \\
& =0,17
\end{aligned}
$$

Menghitung standar deviasi dari distribusi harga rata-rata sub grup dengan cara sebagai berikut :

$$
\begin{gathered}
\sigma_{\bar{x}}=\frac{\sigma}{\sqrt{n}} \\
=\frac{0,17}{\sqrt{5}} \\
=0,08
\end{gathered}
$$

Menghitung batas kontrol atas dan batas kontrol bawah dengan cara sebagai berikut:

$$
\begin{aligned}
\mathrm{BKA} & =\overline{\overline{\mathrm{x}}}+3 \sigma_{\overline{\mathrm{x}}} \\
& =2,43+(3)(0,08) \\
& =2,67 \\
\mathrm{BKB} & =\overline{\overline{\mathrm{x}}}-3 \sigma_{\overline{\mathrm{x}}} \\
& =2,43-(3)(0,08) \\
& =2,19
\end{aligned}
$$

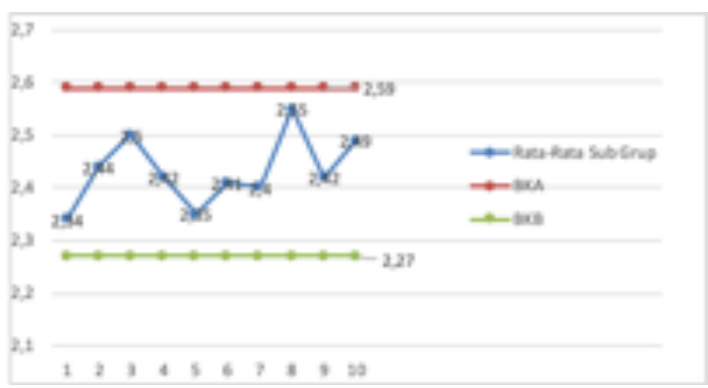

Gambar 1 Grafik keseragaman data meletakan pot kedalam mesin KM SPA

Dengan cara yang sama data lain yang telah di kumpulkan kemudian diuji. Hasil uji keseragaman data yang dapat dilihat pada Tabel 4.

Tabel 4 Uji keseragaman data

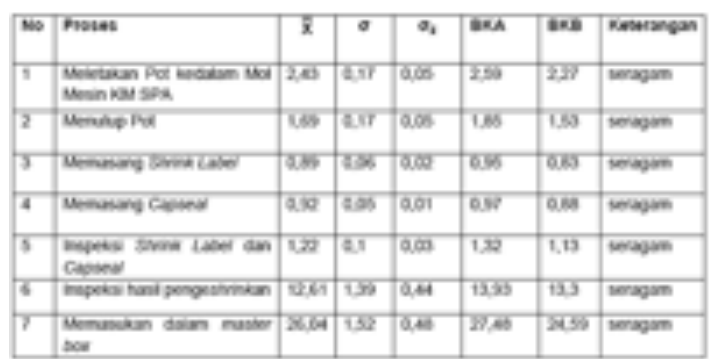

\section{c. Penyesuaian dan Kelonggaran}

Sebelum dilakukan perhitungan waktu baku maka perlu diketahui terlebih dahulu nilai penyesuaian dan kelonggaran yang dimiliki oleh operator yang bersangkutan.

\section{1) Faktor Penyesuaian}

Memasukan Pot dalam Mol Mesin KM SPA dan penetapan penyesuaian (performace rating) tersebut, berdasarkan pertimbangan :

a) Good Skill (C1) :

(1). Kualitas hasil baik

(2). Tampak sebagai pekerja yang cakap

(3). Tidak memerlukan banyak pengawasan

(4). Gerakan-gerakannya terkoordinasi dengan baik.

b) Good Effort (C2) :

(1). Penuh perhatian pada pekerjaannya

(2). Kecepatan baik dan dapat dipertahankan sepanjang hari

(3). Menerima saran-saran dan petunjuk dengan senang

(4). Menggunakan alat-alat yang tepat dengan baik 
c) Good Condition (C) :

Operator bekerja pada ruangan yang bersih dan pencahayaan yang sangat baik, sehingga memudahkan operator untuk melaksanakan tugasnya. Suara kebisingan yang diakibatkan oleh mesin juga masih berada dalam batas wajar untuk pendengaran. Temperatur ruangan juga berada dalam batas normal yang mana tidak terlalu panas dan tidak terlalu dingin, sehingga operator dapat bekerja dengan nyaman.

d) Average Consistency (D) :

Operator bekerja dengan tempo yang cukup stabil, yang mana range kecepatannya masih dapat ditolerir atau berada dalam batas wajar. Opetaror juga tidak banyak melakukan gerakan tambahan yang dirasa kurang penting dan hanya membuang waktu maupun tenaga yang dapat meningkatkan tingkat kelelahan operator. Hal tersebut diakibatkan karena operator telah terlatih untuk melakukan pekerjaannya.

Dengan menggunakan metode Westinghouse, faktor penyesuaian (performace rating) dari operator adalah seperti ditunjukkan pada Tabel 5:

Tabel 5 Faktor penyesuaian pekerjaan memasukan pot dalam Mesin KM SPA

\begin{tabular}{|c|c|c|c|}
\hline perorovance Ratwo & XETEGavaAN & noce & New \\
\hline Nombingen (4) & 6000 & CF & .006 \\
\hline Uhara inton? & 6owe & $Q$ & $+0,00$ \\
\hline Conbs beg iventori! & Gave & c & +060 \\
\hline 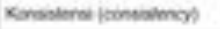 & Avens & D & 0,00 \\
\hline \multicolumn{3}{|c|}{ Jowent } & .075 \\
\hline
\end{tabular}

Maka $P=1+0,10=1,10$

Selanjutnya untuk pekerjaan lainnya faktor penyesuaiannya dapat dilihat pada Tabel 6 sampai dengan Tabel 11.

Tabel 6 Faktor penyesuaian pekerjaan menutup pot

\begin{tabular}{|c|c|c|c|}
\hline PUWONGANCE RATID & 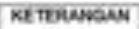 & kooe & new \\
\hline Kotersipots istan & sood & C5 & +205 \\
\hline Wuajeseste & $\operatorname{cosed}$ & Cs & $=408$ \\
\hline 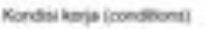 & Cood & c & -902 \\
\hline 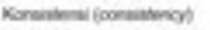 & Anosose & 0 & 000 \\
\hline \multicolumn{3}{|c|}{ sovera } & न्वा \\
\hline
\end{tabular}

Maka $P=1+0,13=1,13$
Tabel 7 Faktor penyesuaian pekerjaan memasang shrink label

\begin{tabular}{|c|c|c|c|}
\hline 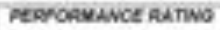 & NETEStwanN & kooe & near \\
\hline 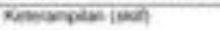 & Gलक & दा & .606 \\
\hline Vaine intores & 0000 & c) & .0 .06 \\
\hline 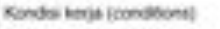 & Averapt & 0 & 400 \\
\hline 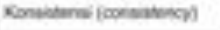 & cood & c & $=009$ \\
\hline \multicolumn{3}{|c|}{ rosery } & -6.12 \\
\hline
\end{tabular}

Maka $P=1+0,12=1,12$

Tabel 8 Faktor penyesuaian pekerjaan memasang capseal

\begin{tabular}{|c|c|c|c|}
\hline 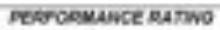 & NETRELUEAN & 2000 & naw \\
\hline Rerampanswer & thad & $\omega$ & .65 \\
\hline Unea inow & Limox & 0 & $4 \infty$ \\
\hline Konds kepa yondbone! & Bewer & 0 & $4 \infty$ \\
\hline 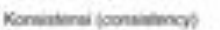 & Exelume & B & .000 \\
\hline \multicolumn{3}{|c|}{ enver } & -505 \\
\hline
\end{tabular}

Maka $P=1+0,06=1,06$

Tabel 9 Faktor penyesuaian pekerjaan inspeksi shrink label dan capseal

\begin{tabular}{|c|c|c|c|}
\hline PETOCANANCE RATIVD & KETESAwan:4 & NOOE & Now \\
\hline 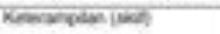 & Exewe & Wo & क्वज्य \\
\hline Uhena intoret & Cood & $\omega$ & +ata \\
\hline Konds bins icondtomi) & Alevape & D & 0,00 \\
\hline 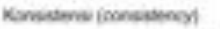 & Alerwon: & D & $\infty, \infty$ \\
\hline \multicolumn{3}{|c|}{ NULAT } & .2 .00 \\
\hline
\end{tabular}

Maka $P=1+0,10=1,10$

Tabel 10 Faktor penyesuaian pekerjaan inspeksi hasil pengeshrinkan

\begin{tabular}{|c|c|c|c|}
\hline 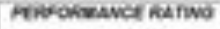 & Nentravedw & Noce & $\mathrm{NeN}$ \\
\hline Retempers lant & 6000 & C. & +00 \\
\hline Ueval itotot & Goved & ca & $+0,06$ \\
\hline 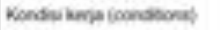 & Amape & 0 & 000 \\
\hline 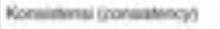 & himas & D & 0,0 \\
\hline
\end{tabular}

Maka $\mathrm{P}=1+0,11=1,11$

Tabel 11 Faktor penyesuaian pekerjaan memasukan produk dalam master box

\begin{tabular}{|c|c|c|c|}
\hline 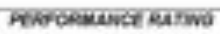 & Nertacueder & woter & nave \\
\hline 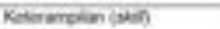 & cood & $\Omega_{2}$ & .00 \\
\hline Uuna inton! & Good & $\omega$ & .600 \\
\hline Kinses kesa inonamone] & Alemper & D & 60 \\
\hline 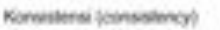 & ooved & $\mathrm{c}$ & .601 \\
\hline \multicolumn{3}{|c|}{ MULAF } & .006 \\
\hline
\end{tabular}

Maka $P=1+0,06=1,06$

\section{2) Faktor Kelonggaran}

Faktor Kelonggaran Pekerjaan Memasukan Pot dalam Mol Mesin KM dapat dilihat pada Tabel 12. 
Tabel 12 Faktor kelonggaran pekerjaan memasukan pot dalam mol mesin KM

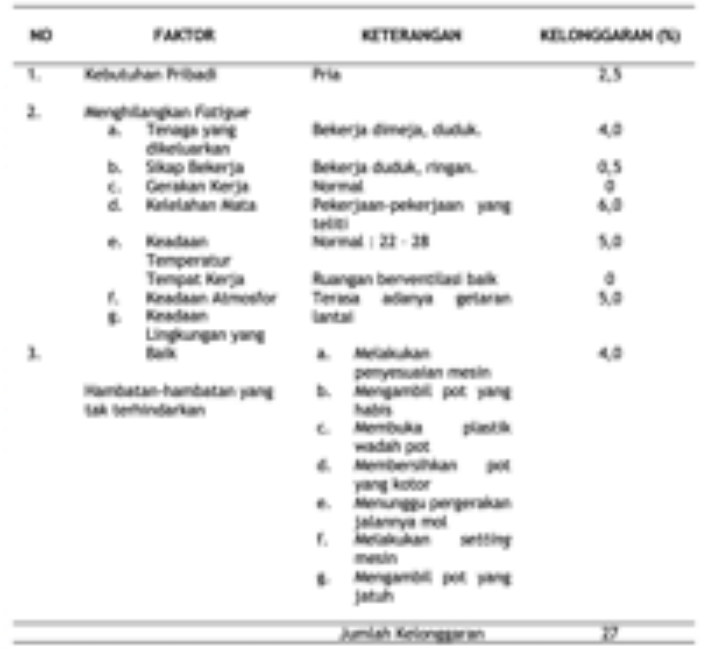

Jadi total kelonggaran (allowance) yang digunakan untuk Pekerjaan Memasukan Pot dalam Mol Mesin KM adalah $27 \%$. Dengan cara yang sama faktor kelonggaran untuk pekerjaan yang lain ditetapkan, hasilnya disajikan pada Tabel 13.

Tabel 13 Faktor kelonggaran

\begin{tabular}{|c|c|c|}
\hline No & Proses & $\begin{array}{c}\text { Allowance } \\
\text { (X) }\end{array}$ \\
\hline 1 & $\begin{array}{l}\text { Meletakan PoR } \\
\text { kedalam Mol Mesin } \\
\text { kO SPA }\end{array}$ & 27 \\
\hline 2 & Menutup Pot & 27 \\
\hline 3 & $\begin{array}{l}\text { Memasang Shrink } \\
\text { Label }\end{array}$ & 28 \\
\hline 4 & Memasang Capseof & 28 \\
\hline 5 & & 30 \\
\hline 6 & $\begin{array}{l}\text { Inspeksi hasil } \\
\text { pengeshrinkan }\end{array}$ & 30 \\
\hline 7 & $\begin{array}{l}\text { Memasukan dalam } \\
\text { master box }\end{array}$ & 22 \\
\hline
\end{tabular}

\section{d. Perhitungan Waktu Siklus}

Waktu siklus kegitan memasukan pot dalam mol mesin KM SPA:

Waktu siklus $=$ Ws $=\frac{\Sigma x}{N}=\frac{145,84}{60}=2,43 \operatorname{detik} / 4$ pcs

Dengan cara yang sama waktu siklus untuk kegiatan dihitung, hasilnya disajikan pada tabel 14.

\section{e. Perhitungan Waktu Normal}

Waktu normal kegiatan memasukan pot dalam mol mesin KM SPA:

Waktu normal $=W n=W s \times p=2,43 \times 1,10$ $=2,67 \mathrm{detik} / 4 \mathrm{pcs}$

Dengan cara yang sama waktu normal untuk kegiatan dihitung, hasilnya disajikan pada tabel 15.

Tabel 14 Perhitungan waktu siklus

\begin{tabular}{|c|c|c|c|}
\hline No & Proses & $\begin{array}{l}\text { Waktu } \\
\text { Siklus } \\
\text { (detik) }\end{array}$ & $\begin{array}{l}\text { Waktu } \\
\text { Siklus } \\
\text { (menit) }\end{array}$ \\
\hline & Meletakan Pot & & \\
\hline 1 & $\begin{array}{l}\text { kedalam Mol Mesin } \\
\text { KM SPA }\end{array}$ & 2,43 & 0,041 \\
\hline 2 & Menutup Pot & 1,69 & 0,028 \\
\hline 3 & $\begin{array}{l}\text { Memasang Shrink } \\
\text { Label }\end{array}$ & 0,89 & 0,015 \\
\hline 4 & Memasang Copseal & 0,92 & 0,015 \\
\hline & $\begin{array}{l}\text { Inspelsi Shrink Label } \\
\text { dan Capseal }\end{array}$ & 1,22 & 0,020 \\
\hline 6 & $\begin{array}{l}\text { Inspeksi hasil } \\
\text { perveshrinkan }\end{array}$ & 13,00 & 0,217 \\
\hline 7 & $\begin{array}{l}\text { Memasukan dalam } \\
\text { moster box }\end{array}$ & 26,04 & 0,434 \\
\hline
\end{tabular}

Tabel 15 Perhitungan waktu normal

\begin{tabular}{|c|c|c|c|}
\hline No & Proses & $\begin{array}{l}\text { Waktu } \\
\text { Normal } \\
\text { (detik) }\end{array}$ & $\begin{array}{l}\text { Waktu } \\
\text { Nermal } \\
\text { (menit) }\end{array}$ \\
\hline 1 & $\begin{array}{l}\text { Meletakan Pot } \\
\text { kedalam Mol Mesin } \\
\text { KM SPA }\end{array}$ & 2,67 & 0,045 \\
\hline 2 & Menutup Pot & 1,91 & 0,032 \\
\hline 3 & $\begin{array}{l}\text { Memasang Shrink } \\
\text { Labef }\end{array}$ & 1,00 & 0,017 \\
\hline 4 & Memasang Capseal & 0,98 & 0,016 \\
\hline 5 & $\begin{array}{l}\text { Inspeksi Shrink } \\
\text { Label dan Copseol }\end{array}$ & 1,35 & 0,023 \\
\hline 6 & $\begin{array}{l}\text { Inspeksil hasil } \\
\text { pengeshrinkan }\end{array}$ & 14,43 & 0,241 \\
\hline 7 & $\begin{array}{l}\text { Memasukan dalam } \\
\text { moster box }\end{array}$ & 27,60 & 0,460 \\
\hline
\end{tabular}

\section{f. Perhitungan Waktu Baku / Standar}

Waktu baku kegiatan memasukan pot dalam mol mesin KM SPA

$$
\begin{aligned}
\text { Waktu baku } & =\text { Wn } \times \frac{100 \%}{100 \%-\% \text { Allowance }} \\
& =2,67 \times \frac{100 \%}{100 \%-27 \%} \\
& =3,66 \text { detik/4 pcs }
\end{aligned}
$$

Dengan cara yang sama waktu baku kegiatan yang lain dapat dihitung. Hasilnya disajikan pada tabel 16 .

Tabel 16 Perhitungan waktu baku

\begin{tabular}{llcc}
\hline No & \multicolumn{1}{c}{ Proses } & $\begin{array}{c}\text { Waktu } \\
\text { Baku } \\
\text { (detik) }\end{array}$ & $\begin{array}{c}\text { Waktu } \\
\text { Baku } \\
\text { (menit) }\end{array}$ \\
\hline 1 & $\begin{array}{l}\text { Meletakan Pot } \\
\text { kedalam Mol Mesin } \\
\text { KM SPA }\end{array}$ & 3,66 & 0,061 \\
2 & $\begin{array}{l}\text { Menutup Pot } \\
\text { Memasang Shrink }\end{array}$ & 2,62 & 0,044 \\
4 & $\begin{array}{l}\text { Lebel } \\
\text { Memasang Capseal }\end{array}$ & 1,39 & 0,023 \\
5 & $\begin{array}{l}\text { Inspeksi Shrink } \\
\text { Label dan Capseal }\end{array}$ & 1,92 & 0,032 \\
6 & $\begin{array}{l}\text { Inspeksi hasil } \\
\text { pengeshrinkan }\end{array}$ & 20,61 & 0,3435 \\
7 & $\begin{array}{l}\text { Memasukan dalam } \\
\text { master bax }\end{array}$ & 35,38 & 0,5897 \\
\hline
\end{tabular}


Peramalan Jumlah Permintaan per Bulan Periode Agustus 2018-Juli 2019

Pada tabel 17 berikut ini ditampilkan data jumlah permintaan per bulan periode Januari 2017 - Juli 2018. Berdasarkan pola permintaan dari masing-masing varian lulur mandi Purbasari yang cenderung memiliki pola rata atau tidak terlalu variatif.

Tabel 17 Jumlah permintaan per bulan produk lulur mandi Purbasari kemasan 235 gr.

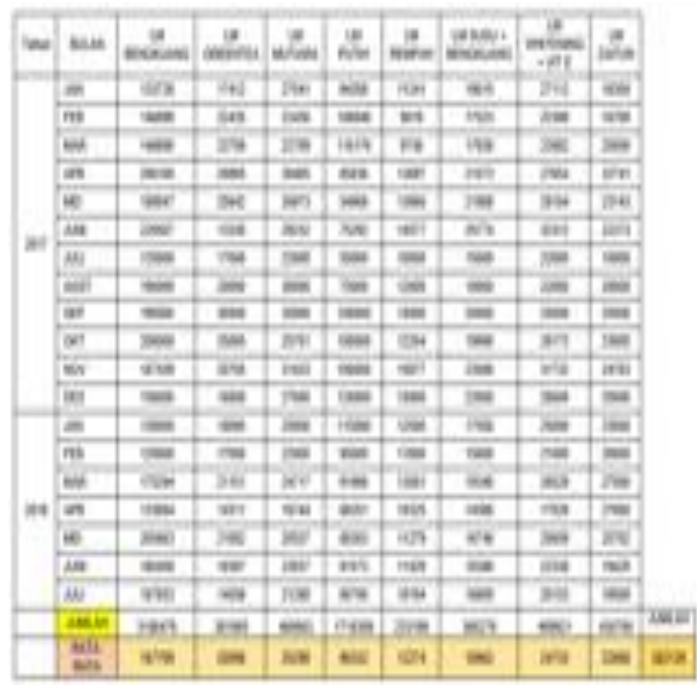

Berdasarkan tabel diatas maka diperkirakan jumlah permintaan untuk Agustus 2018 - Juli 2019 adalah 382126 unit produk.

\section{Analisis Beban Kerja (Workload Analysis)}

Data jumlah operator pada masingmasing proses pada saat sekarang seperti ditunjukkan pada tabel 18 berikut:

Tabel 18 Jumlah operator pada setiap proses pada saat sekarang

\begin{tabular}{llc}
\hline No & \multicolumn{1}{c}{ Proses } & $\begin{array}{c}\text { Jumlah } \\
\text { Operator }\end{array}$ \\
\hline 1 & Meletakan Pot kedalam & 1 \\
2 & Mol Mesin KM SPA & 3 \\
3 & Menutup Pot & 2 \\
4 & Memasang Shrink Label & 2 \\
5 & Inspeksi Shrink Label dan & 2 \\
& $\begin{array}{l}\text { Capseal } \\
6\end{array}$ & 1 \\
7 pengeksi hasil & Memasukan dalam master & 1 \\
\hline
\end{tabular}

a. Beban kerja pada proses memasukkan pot ke dalam mesin KM SPA

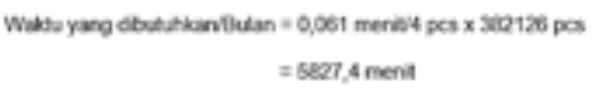

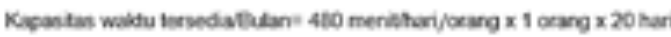

$$
=9600 \text { menth }
$$

Beban Kerja por Bulan $=\frac{5427.4 \text { meet }}{560 \text { menta }} \times 100 \%$

$$
\text { *\$1 \$ }
$$

b. Beban kerja memasang tutup

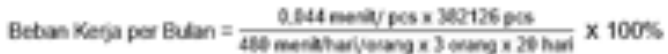

$$
\begin{aligned}
& -5 a \%
\end{aligned}
$$

c. Beban Kerja memasang Shrink Label

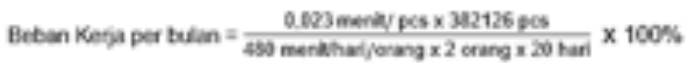

$$
=48 \%
$$

d. Beban Kerja memasang Capseal

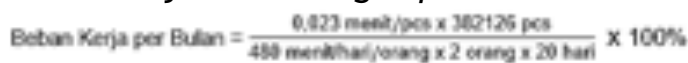

$$
=46 \mathrm{~s}
$$

e. Beban Kerja Inspeksi Shrink Label dan Capseal

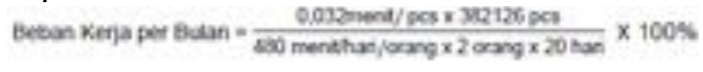

$$
=64 \%
$$

f. Beban Kerja Inspeksi Hasil Pengeshrinkan

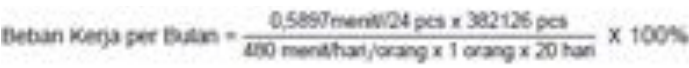

$$
\begin{aligned}
& =96 \leqslant
\end{aligned}
$$

g. Beban Kerja Memasukan Produk kedalam Master Box

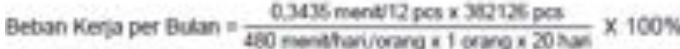

$$
\begin{aligned}
& =114 \%
\end{aligned}
$$

\section{Perencanaan Jumlah Tenaga Kerja Yang Sesuai}

a. Proses Memasang Pot Pada Mesin KM SPA Jumlah pekerja $=\frac{\text { Waktu baku } \times \text { Demand }}{\text { Waktu tersedia }}$

$$
\begin{aligned}
& =\frac{\text { Waktu tersedia }}{480 \mathrm{menit} / 4 \mathrm{pcs} \times 382126 \mathrm{pcs}} \\
& =0,6 \mathrm{orani} / \mathrm{rang} / \mathrm{hari} \times 20 \mathrm{hari} \\
& =1 \mathrm{orang}
\end{aligned}
$$

b. Proses Menutup Pot

$$
\begin{aligned}
\text { Jumlah pekerja } & =\frac{\text { Waktu baku } \times \text { Demand }}{\text { Waktu tersedia }} \\
& =\frac{0,044 \mathrm{menit} / \mathrm{pcs} \times 382126 \mathrm{pcs}}{480 \mathrm{menit} / \mathrm{orang} / \mathrm{hari} \times 20 \mathrm{hari}} \\
& =1,7 \mathrm{orang}=2 \mathrm{orang}
\end{aligned}
$$

c. Proses Memasang Shrink Label

$$
\begin{aligned}
\text { Jumlah pekerja } & =\frac{\text { Waktu baku } \times \text { Demand }}{\text { Waktu tersedia }} \\
& =\frac{0,023 \mathrm{menit} / \mathrm{pcs} \times 382126 \mathrm{pcs}}{480 \mathrm{menit} / \mathrm{orang} / \mathrm{hari} \times 20 \mathrm{hari}} \\
& =1 \mathrm{orang}
\end{aligned}
$$

d. Proses Memasang Capseal

Jumlah pekerja $=\frac{\text { Waktu baku } \times \text { Demand }}{\text { Waktu tersedia }}$ 


$$
\begin{aligned}
& =\frac{0,023 \mathrm{menit} / \mathrm{pcs} \times 382126 \mathrm{pcs}}{480 \mathrm{menit} / \mathrm{orang} / \text { hari } \times 20 \mathrm{hari}} \\
& =1 \mathrm{orang}
\end{aligned}
$$

e. Proses Inspeksi Shrink Label dan Capseal Jumlah pekerja $=\frac{\text { Waktu baku } \times \text { Demand }}{\text { Waktu tersedi }}$

$$
\begin{aligned}
& =\frac{0,032 \mathrm{menit} / \mathrm{pcs} \times 382126 \mathrm{pcs}}{480 \mathrm{menit} / \mathrm{orang} / \mathrm{hari} \times 20 \mathrm{hari}} \\
& =1,3 \mathrm{orang}=2 \mathrm{orang}
\end{aligned}
$$

f. Proses Memasang Pot Pada Mesin KM SPA Jumlah pekerja $=\frac{\text { Waktu baku } \times \text { Demand }}{\text { Waktu tersedia }}$

$$
\begin{aligned}
& =\frac{0,061 \mathrm{menit} / 4 \mathrm{pcs} \times 382126 \mathrm{pcs}}{480 \mathrm{menit} / \mathrm{orang} / \mathrm{hari} \times 20 \mathrm{hari}} \\
& =0,6 \mathrm{orang}=1 \mathrm{orang}
\end{aligned}
$$

g. Proses Menutup Pot

$$
\begin{aligned}
\text { Jumlah pekerja }=\frac{\text { Waktu baku } \times \text { Demand }}{\text { Waktu tersedia }} \\
\qquad=\frac{0,044 \text { menit } / \mathrm{pcs} \times 382126 \mathrm{pcs}}{480 \mathrm{menit} / \mathrm{orang} / \mathrm{hari} \times 20 \mathrm{hari}} \\
=1,7 \mathrm{orang}=2 \mathrm{orang}
\end{aligned}
$$

h. Proses Memasang Shrink Label

$$
\begin{aligned}
\text { Jumlah pekerja }=\frac{\text { Waktu baku } \times \text { Demand }}{\text { Waktu tersedia }} \\
=\frac{0,023 \mathrm{menit} / \mathrm{pcs} \times 382126 \mathrm{pcs}}{480 \mathrm{menit} / \mathrm{orang} / \mathrm{hari} \times 20 \mathrm{hari}} \\
=1 \mathrm{orang}
\end{aligned}
$$

i. Proses Memasang Capseal

Jumlah pekerja $=\frac{\text { Waktu baku } \times \text { Demand }}{\text { Waktu tersedia }}$

$$
\begin{aligned}
\text { Waktu tersedia } & \\
= & \frac{0,023 \mathrm{menit} / \mathrm{pcs} \times 382126 \mathrm{pcs}}{480 \mathrm{menit} / \mathrm{orang} / \mathrm{hari} \times 20 \mathrm{hari}} \\
= & 1 \mathrm{orang}
\end{aligned}
$$

j. Proses Inspeksi Shrink Label dan Capseal Jumlah pekerja $=\frac{\text { Waktu baku } \times \text { Demand }}{\text { Waktu tersedia }}$

$$
\begin{gathered}
=\frac{\text { Waktu tersedia }}{0,032 \mathrm{menit} / \mathrm{pcs} \times 382126 \mathrm{pcs}} \\
=180 \mathrm{menit} / \mathrm{orang} / \mathrm{hari} \times 20 \mathrm{hari} \\
=1,3 \mathrm{orang}=2 \mathrm{orang}
\end{gathered}
$$

k. Proses Inspeksi Hasil Pengeshrinkan Berdasarkan perhitungan beban kerja proses inspeksi hasil pengeshrinkan maka diperoleh beban kerja yang berlebih yaitu sebanyak $114 \%$, maka dari itu perlu dilakukan analisis secara lebih lanjut untuk mengetahui mana yang lebih baik antara menambahkan jumlah tenaga kerja atau menambahkan jam kerja lembur.

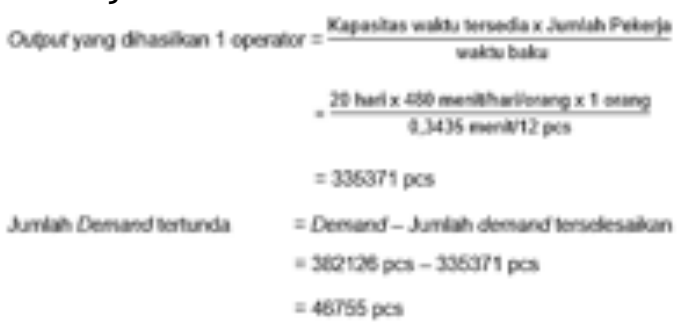

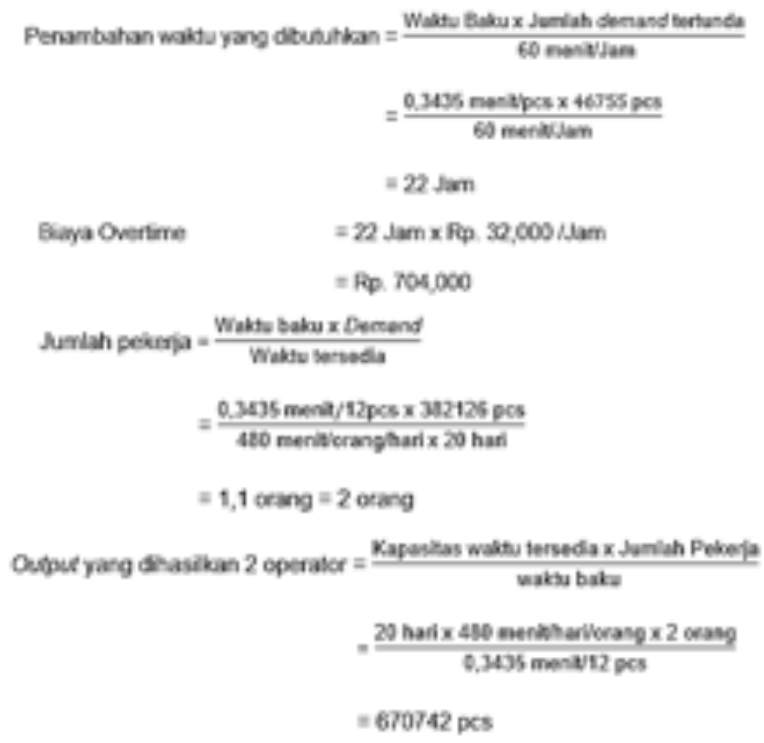

Total Biaya = (Jumlah Operator $x$ Bisya Regular Tame $)+$ Biaya Overtime

$=(1 \operatorname{crang} \times$ Rg. $3,483,000 /$ orang $)+$ Rp. 704,000

= Ra $4,187,000$

Tabel 19 Usulan perbaikan pada proses inspeksi hasil pengeshrinkan

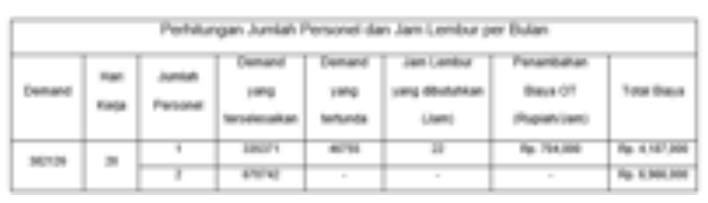

Berdasarkan hasil perhitungan di atas setelah dilakukan perbandingan dalam segi biaya antara penambahan tenaga atau penambahan jam lembur (overtime) maka dipilihlah alternatif penambahan jam lembur (overtime) yaitu sebanyak 22 jam/bulan dengan biaya yang lebih rendah yaitu sebesar Rp. 4,187,000.

l. Proses Memasukkan Produk kedalam Master Box

Jumlah pekerja $=\frac{\text { Waktu baku } \times \text { Demand }}{\text { Waktu }}$

$$
\begin{aligned}
& =\frac{0,5897 \mathrm{menit} / 24 \mathrm{pcs} \times 382126 \mathrm{pcs}}{480 \mathrm{menit} / \mathrm{orang} / \mathrm{hari} \times 20 \mathrm{hari}} \\
& =1 \mathrm{orang}
\end{aligned}
$$

\section{SIMPULAN}

Dari uaraian pembahasan dapat diambil beberapa kesimpulan diantaranya :

1) Berdasarkan hasil analisis dan pengolahan data yang telah dilakukan, maka didapat waktu baku dari setiap proses yang terdapat di bagian filling dan juga packing. 
- Waktu baku pada bagian filling

- Proses meletakan pot dalam mesin KM SPA : 0,061 menit/4 pCs

- Proses menutup pot :0,044 menit/pcs.

- Waktu baku pada bagian packing

- Proses memasang shrink label:0,023 menit/pcs

- Proses memasang capseal: 0,023menit/pcs

- Poses inspeksi shrink label dan capseal : 0,032 menit/pcs

- Proses inspeksi hasil pengeshrinkan : 0,3435 menit/12 pcs

- Proses memasukan dalam master box : 0,5897 menit/24 pcs.

2) Berdasarkan analisis beban kerja maka dapat diketahui jumlah tenaga kerja yang diperlukan pada setiap proses yang terdapat di bagian filling dan juga packing adalah seperti ditunjukkan pada tabel 20 berikut:

Tabel 20 Rekapitulasi usulan jumlah tenaga kera kerja

\begin{tabular}{|c|c|c|c|}
\hline No & Proses & $\begin{array}{c}\text { Jumlah } \\
\text { Tenaga } \\
\text { Kerja } \\
\text { Sekarang } \\
\text { (orang) }\end{array}$ & $\begin{array}{l}\text { Usulan } \\
\text { Setelah } \\
\text { dihitung } \\
\text { Beban } \\
\text { Kerja } \\
\text { (orang) }\end{array}$ \\
\hline 1 & $\begin{array}{l}\text { Meletakan Pot kedalam } \\
\text { Mol Mesin KM SPA }\end{array}$ & 1 & 1 \\
\hline 2 & Menutup Pot & 3 & 2 \\
\hline 3 & Memasang Shrink Label & 2 & 1 \\
\hline 4 & Memasang Copseal & 2 & 1 \\
\hline 5 & $\begin{array}{l}\text { Inspeksi Shrink Label } \\
\text { dan Copreal }\end{array}$ & 2 & 2 \\
\hline 6 & $\begin{array}{l}\text { Inspeiksi hasil } \\
\text { pengeshrinkan }\end{array}$ & 1 & $\stackrel{1+}{\text { Overtime }}$ \\
\hline 7 & $\begin{array}{l}\text { Memasukan dalam } \\
\text { master box }\end{array}$ & 1 & 1 \\
\hline
\end{tabular}

\section{DAFTAR PUSTAKA}

Dedi C, 1994, Perhitungan Waktu Standar dan Penyeimbang Beban Kerja Operator Jalur Permesinan Crankshaf Type S 89 pada PT ADM P-2, Skripsi, Fakultas Teknik, Universitas Indonesia: Jakarta.

Hasibuan, Malayu S.P, Manajemen Sumber Daya Manusia, Edisi Revisi, Jakarta : Bumi Aksara, 2005.

Purnomo, H., Pengantar Teknik Industri, Yogyakarta: Graha Ilmu, 2003.

Sarah N.A, 2017, Pengukuran Waktu Baku dan Analisis Beban Kerja pada Proses
Produksi Gear Cover Packing (M-013) di PT. Covac Indonesia, Skripsi, Fakultas Teknik, Universitas Pancasila: Jakarta.

Sutalaksana, Iftikar Z, Anggawisastra, Ruhana. Tjakraatmadja, Jann H, Teknik Perancangan Sistem kerja, Bandung : ITB, 2006. 